\author{
Marin Keršić, LL. M. \\ asistent Pravnog fakulteta Sveučilišta u Splitu ${ }^{1}$
}

\title{
ĐENOVEŠKA ŠKOLA PRAVNOG REALIZMA
}

\author{
UDK: 340.12 \\ 340.15 \\ DOI: $10.31141 / z r p f s .2020 .57 .137 .829$ \\ Pregledni znanstveni rad \\ Primljeno: 15. II. 2020.
}

\begin{abstract}
U radu su predstavljene neke temeljne ideje đenoveškog pravnog realizma, smjera u teoriji prava koji se javlja u drugoj polovici 20. st. u Italiji, te njegovi najistaknutiji predstavnici. Cilj je rada ukazati na relevantnost nekih ideja talijanske teorije prava za hrvatsku pravnu znanost te njihove praktične implikacije. Strukturno, u radu su prvo izložena obilježja pravnog realizma općenito (skandinavskog i američkog), a potom i obilježja đenoveškog pravnog realizma kao jedne njegove varijante. Predstavnici škole o kojima se u radu govori su Giovanni Tarello, Riccardo Guastini, Paolo Comanducci, Mauro Barberis, Pierluigi Chiassoni i Giovanni Battista Ratti, a u radu se razmatra sljedeće: ideja o središnjoj ulozi tumačenja i višeznačnosti samog pojma; popis od 15 interpretativnih argumenata koji može (ili bi trebao) služiti kao svojevrstan alat tumačima; karakteristike pravila i načela (kao dviju vrsta normi) i njihovo razlikovanje; tumačenje i način primjene ustavnih načela; implicitne (prešutne) norme; antinomije i načini rješavanja sukoba koji nastanu između samih kriterija za rješavanje antinomija; primjena logike u pravu kroz primjenu teorije skupova na pravo te pojam otklonjivosti (derogabilnosti).
\end{abstract}

Ključne riječi: talijanska teorija prava, pravni realizam, pravna norma, tumačenje, antinomije

\section{UVOD}

U ovom radu bit će predstavljene neke od glavnih ideja i predstavnika đenoveškog pravnog realizma, smjera u teoriji prava koji se javlja u drugoj polovici 20. stoljeća u Italiji. Predstavljanje jedne utjecajne suvremene teorije prava kroz teme kojima su se bavili njeni predstavnici ima za cilj ukazati na spoznaje koje mogu biti od koristi hrvatskoj pravnoj znanosti i pravu općenito. ${ }^{2}$ Još je Nikola Visković pratio trendove u tada aktualnoj talijanskoj teoriji prava (Norberto Bobbio i Giovanni

1 Marin Keršić, LL.M. (Frankfurt am Main), Domovinskog rata 8, 21000 Split, e-mail: marin. kersic@pravst.hr.

2 Radi se o sljedećem: nekim razmatranjima o tumačenju i jednom mogućem popisu pravnih argumenata; razlikovanju pravila i načela kao dviju vrsta normi; tumačenju i načinu primjene ustavnih načela; implicitnim (prešutnim) normama; diskusijama o etičkim i metaetičkim pitanjima; ideji pravnog evolucionizma; nekim razmatranjima o antinomijama, posebno o načinima rješavanja sukoba koji nastanu između samih kriterija za rješavanje antinomija; primjeni simboličke logike i teorije skupova na pravo te pojma otklonjivosti (derogabilnosti). 
Tarello), a Luka Burazin je nastavio s tim (Riccardo Guastini). ${ }^{3} \mathrm{U}$ tom smislu ovim radom autor namjerava dati jedan prilog povezivanju suvremene hrvatske teorije prava sa suvremenom talijanskom teorijom prava. Strukturno, prvo se sažeto iznose obilježja pravnog realizma općenito (skandinavskog i američkog), zatim obilježja đenoveškog pravnog realizma kao jedne njegove varijante, a nakon toga su predstavljeni istaknuti predstavnici škole: Giovanni Tarello, Riccardo Guastini, Paolo Comanducci, Mauro Barberis, Pierluigi Chiassoni i Giovanni Battista Ratti. U zaključku, ukazuje se na neke od ideja spomenutih autora za koje autor smatra da zavređuju dodatnu pozornost u hrvatskoj pravnoj znanosti zbog njihovih praktičnih implikacija.

\section{PRAVNI REALIZAM - OPĆENITO}

Teorije u pravu mogu se tradicionalno podijeliti na prirodnopravne (jusnaturalističke) i pozitivnopravne (juspozitivističke), ${ }^{4}$ no tijekom 20. stoljeća dolazi do daljnjih podjela u kojima se, uz druge smjerove, javlja i pravni realizam. ${ }^{5}$ Pravni realizam obilježava empiristički pristup ontologiji prava: pravo je, prema pravnim realistima, ,ukupnost društvenih činjenica određene vrste“ (a ne apstraktnih entiteta poput normi i vrijednosti). ${ }^{6}$ Izraz realizam, kako navodi Vrban, može se protumačiti i kao fakticizam ili empirizam, u smislu da se pravni realisti usredotočuju na ,shvaćanje prava kroz ljudsko ponašanje, dakle ono što se uobičajeno smatra 'primjenom' prava“. 7 Iz perspektive pravnih realista, ,pravom“ (odnosno društvenim činjenicama koje čine pravo) mogu se smatrati tri stvari, kako navodi Guastini: prvo, ukupnost normativnih tekstova; drugo, ukupnost normi koje

3 N. Bobbio, Eseji iz teorije prava (prijevod N. Visković i Ž. Anzulović), Logos, Split, 1988.; G. Tarello, „Argumentacija tumačenja i sheme obrazlaganja u pridavanju značenja normativnim tekstovima“ (prijevod VIII. poglavlja knjige L’interpretazione della legge, N. Visković i S. Šućin), Zbornik za teoriju prava 4, 1990.; R. Guastini, Sintaksa prava (prijevod L. Burazin), Naklada Breza, Zagreb, 2016.

4 N. Bobbio, op. cit. u bilj. 2, str. 19-30; N. Visković, Teorija države i prava, Birotehnika, Zagreb, 2006., IV. poglavlje; N. Visković, Pojam prava: prilog integralnoj teoriji prava, Logos, Split, 1981., str. 23 i dalje (Visković ovdje razlikuje prirodnopravne, legalističke, normativističke, sociološke i integralne pravne teorije, svrstavajući pravni realizam među sociološke teorije o pravu; ibid., str. 29). Takva klasifikacija odgovara jednoj široj klasifikaciji, u kojoj se pravni realizam svrstava među sociološke teorije o pravu, a sociološke teorije u pravu u pozitivnopravne (juspozitivističke).

5 M. Barberis, Manuale di filosofia del diritto, Giappichelli, Torino, str. 27. Usp. D. Vrban, Država i pravo, Golden Marketing, Zagreb, 2003., str. 571-573.

6 R. Guastini, ,Redefinicija pravnog realizma“ (prijevod M. Franić), Revus 19, str. 87.

7 Usp. D. Vrban, op. cit. u bilj. 4, str. 571. 
su plod „kreativnog“ tumačenja tih normativnih tekstova i manipulacije njima i treće, ukupnost važećih normi. ${ }^{8}$

Pravni realizam predstavlja svojevrstan otpor pravnom pozitivizmu s antiformalističkih pozicija, te se tako javljaju skandinavski i američki pravni realizam. ${ }^{9}$ Talijanska teorija prava u 20. st. u bitnom je obilježena pravnim realizmom. ${ }^{10}$ Postavlja se pitanje koje su temeljne karakteristike pravnog realizma u teoriji prava o odnosu na jusnaturalizam i juspozitivizam. Barberis navodi i obrazlaže sljedeće karakteristike pravnog realizma: ${ }^{11}$

1) teza o odvojivosti (prava i morala): pravo, koliko god ono bilo nepravedno ili u suprotnosti s moralom, i dalje je pravo te između prava i morala postoje samo kontingentni, a ne nužni odnosi; ${ }^{12}$

8 Usp. R. Guastini, op. cit. u bilj. 5, str. 91. O tumačenju vidi i R. Guastini, op. cit. u bilj. 2, str. 351-358. Guastini razlikuje spoznajno (kognitivno) tumačenje ili tumačenje-utvrđenje, ,koje se sastoji u utvrđivanju različitih mogućih značenja normativnog teksta (na temelju jezičnih pravila, različitih tehnika tumačenja u uporabi, dogmatskih teza raširenih u doktrini itd.), pritom ne izabirući nijedno od njih“ i odlučujuće (decizivno) tumačenje, ili tumačenje-odluku, „koje se sastoji u izboru određenog značenja, odbacujući preostala“. U okviru odlučujućeg (decizivnog) tumačenja, Guastini razlikuje standardno odlučujuće tumačenje, u kojem se ,tumačenjska odluka sastoji u izboru jednog od značenja u okviru značenja utvrđenih (ili utvrdivih) spoznajnim tumačenjem“ i stvaralačko (kreativno) tumačenje, ili tumačenje-stvaranje, u kojem se ,tumačenjska odluka sastoji u pripisivanju tekstu 'novog' značenja, koje nije obuhvaćeno onima utvrdivim u okviru spoznajnog tumačenja“. Za ilustraciju ove tri vrste tumačenja, Guastini navodi primjer višeznačne odredbe $\mathrm{O}$ koja se može razumjeti na način da izražava normu $\mathrm{N}_{1}$ ili normu $\mathrm{N}_{2}$. Spoznajno (kognitivno) tumačenje takve odredbe izrazit će se iskazom „O može značiti $\mathrm{N}_{1}$ ili $\mathrm{N}_{2}$ “. Standardno odlučujuće tumačenje takve odredbe će se izraziti iskazom „O znači N “ ili iskazom „,O znači N “, dok će se stvaralačko (kreativno) tumačenje izraziti iskazom ,O znači N “. Vidi R. Guastini, op. cit. u bilj. 2, str. 354-355. Za kritike navedenog shvaćanja tumačenja, vidi G. Pino, „Interpretazione cognitiva, interpretazione decisoria, interpretazione creativa“", Rivista di Filosofia del diritto 1, 2013., str. 77-102.

9 M. Barberis, op. cit. u bilj. 4, str. 27. Vidi i S. Castignone, Diritto, linguaggio, realtà. Saggi sul realismo giuridico, Giappichelli, Torino, 1995., posebno IV. dio Il realismo guiridico scandinavo $e$ americano, str. 273-291. Usp. i D. Vrban, op. cit. u bilj. 4, str. 571.

10 C. Faralli, „Legal Philosophy in Italy in the 20th Century“, A Treatise on Legal Philosopgy and General Jurisprudence 12, Springer, Dordrecht, 2016., str. 406 i dalje; L. Gianformaggio, „Realismi giuridici italiani“, Analisi e diritto, Giappichelli, Torino, 1991., str. 176. Više o pravnom realizmu, posebno o Alfu Rossu, vidi i u R. Guastini, „Dalle fonti alle norme“, Analisi e diritto, Giappichelli, Torino, 1992., str. 83 i dalje. O Alfu Rossu i skandinavskom pravnom realizmu pisao je i N. Visković, „Alf Ross“, Zbornik radova Pravnog fakulteta u Splitu 18, str. 41-56. O pravnom realizmu vidi i u B. Leiter, „Legal Realisms, Old and New“, Valparaiso University Law Review 47, str. 949-964. Vidi i http:// www.enciklopedija.hr/Natuknica.aspx?ID=49999 (4. XI. 2019.).

11 M. Barberis, op. cit. u bilj. 4, str. 27-33; M. Barberis, „El realismo jurídico europeo-continental“, Enciclopedia de filosofía y teoría del derecho 1, Instituto de Investigaciones Jurídicas, UNAM, Ciudad de México, 2015., str. 235-238.

12 O nužnim i kontingentnim odnosima, vidi R. Guastini, op. cit. bilj. 2, str. 36-37. Odnos je nužan, kako navodi Guastini, „,kada ne može ne postojati (postoji kakve god bile okolnosti)“, dok je odnos kontingentan ,kada može postojati ili ne postojati (ovisno o okolnostima, ovisno o tome kako stoje stvari)“. Nužni su, kako dalje navodi Guastini, pojmovni odnosi (odnosi među pojmovima), a kontingentni su činjenični odnosi (odnosi među činjenicama). Kad se govori o povezanosti prava i morala u kontekstu teze o odvojivosti, govori se o tome da ne postoji pojmovno nužni odnos između prava i morala, odnosno da moral ne utječe na kriterije važenja prava. O pravnom pozitivizmu i o tezi o odvojivosti (separability thesis), vidi https://plato.stanford.edu/entries/legal-positivism/ (21. X. 2019.). 
2) etički subjektivizam: prosudbe o vrijednostima nisu ni istinite ni neistinite (nemaju istinosnu vrijednost), nisu objektivno pravedne ni nepravedne, nego su samo subjektivne (etički emotivizam).

3) interpretativni skepticizam: svaki sudski slučaj je težak; svaka pravna odredba ima više značenja.

Što se tiče prve teze, kako navodi Barberis, za pravne realiste pravo i moral su i empirijski odvojeni, a ne samo analitički odvojivi: dok ,pravo“ upućuje na činjenice, koje su objektivne, ,moral“ upućuje na vrijednosti, koje su subjektivne. ${ }^{13}$ Pravna doktrina i pravna teorija, prema pravnim realistima, trebaju se baviti činjenicama, a ne vrijednostima, a prije svega, kako ističe Barberis, ne bi trebale vrednovati pravo, budući da su takva vrednovanja samo subjektivni iskaz onoga tko vrednuje. ${ }^{14}$ Etički je subjektivizam zajednički pravnim pozitivistima i pravnim realistima, međutim tu postoje razlike u stupnju između metaetičkih pozicija. ${ }^{15}$ Karakteristika svih pravnih realista jest interpretativni skepticizam. ${ }^{16}$ Neki od pravnih realista takozvani su radikalni skeptici po tom pitanju, te smatraju da je tumačenje (interpretacija) autentično stvaranje prava, dok drugi, tzv. umjereni skeptici, smatraju da je tumačenje samo sudjelovanje u proizvodnji prava. ${ }^{17}$ Interpretativni skepticizam kao obilježje đenoveške škole, prema Chiassoniju, karakterizira nekoliko glavnih teza: ${ }^{18}$

1) interpretativni iskazi su slični stipulativnim definicijama $;^{19}$

2) interpretativna aktivnost nema spoznajni, nego preskriptivni karakter;

3) za utvrđivanje preskriptivnog karaktera tumačenja dovoljno je promotriti što rade pravnici kada tumače jedan normativni tekst;

13 M. Barberis, op. cit. u bilj. 4, str. 27-28. Tako najpoznatiji predstavnik skandinavskog pravnog realizma Alf Ross kaže sljedeće: "The function of the doctrinal study of law is to give an account of a certain individual national system of norms...All these systems are facts whether we like them or not. In any case we need a term to describe these facts and it is purely a matter of terminology without any moral implications whether for this purpose the term 'law' or any other term is chosen." A. Ross, On Law and Justice, University of California Press, Berkeley, 1958., str. 31.

14 M. Barberis, op. cit. u bilj. 4, str. 28. Usp. i L. Gianformaggio, op. cit. u bilj. 9, str. 160: “... nel considerare il diritto come fatto piuttosto che come valore, come essere piuttosto che come dover essere, come mezzo piuttosto che come fine...".

15 M. Barberis, op. cit. u bilj. 4, str. 28. Dok pravni pozitivisti smatraju da su vrijednosni sudovi subjektivni, za pravne realiste, posebno one skandinavske, oni su izraz emocija subjekta. Riječ je, zapravo, kako Barberis ističe, o varijacijama unutar pozicije etičkog subjektivizma.

16 M. Barberis, „Genoa's realism: A Guide for the Perplexed“, Revista Brasilera de Filosofia 240, 2013., str. 15.; P. Chiassoni, „L'inelutabile scetticismo della “scuola genovese”, Analisi e diritto, Giappichelli, Torino, 1998., str. 21.

17 M. Barberis, op. cit. u bilj. 4, str. 29. Usp. s R. Guastini, ,Realismo e antirealismo nella teoria dell' interpretazione“, Ragion pratica 17, 2001., str. 43-52.

18 P. Chiassoni, op. cit. u bilj. 15, str. 21-22.

19 Više o stipulativnim definicijama vidi u R. Guastini, op. cit. u bilj. 2, str. 19. 
4) neustika preskriptivnih pravnih iskaza utječe na njihovu frastiku, što ih ostavlja posebno neodređenima. ${ }^{20}$

Ako bi sažeto trebali definirati pravni realizam, moglo bi se reći, onako kako ga definira Barberis, da je to ,inačica pozitivizma koja pravosuđenje pretpostavlja zakonodavstvu. (...) Radikalno realistička teorija prava smatra pak pravosuđenje - rješavanje sporova, dijeljenje pravde među strankama - općenitijom i bitnijom funkcijom od zakonodavstva, koje postaje prije svega način kontroliranja pravosuđenja“. ${ }^{21}$

\section{3. ĐENOVEŠKI PRAVNI REALIZAM}

Đenoveški je pravni realizam varijanta pravnog realizma, uz (starije) i poznatije verzije - skandinavski i američki. ${ }^{22}$ Osnivač đenoveške škole pravnog realizma jest Giovanni Tarello (1934. - 1987.), jedan od najistaknutijih talijanskih pravnika, filozof i povjesničar prava. Od brojnih pripadnika škole, u ovom će radu biti spomenuti neki (najistaknutiji) od njih: Riccardo Guastini (1946.), Paolo Comanducci (1950.), Mauro Barberis (1956.), Pierluigi Chiassoni (1961.) i Giovanni Battista Ratti (1975.). ${ }^{23}$

20 Pojam neustike i frastike (neustic i phrastic) uveo je R. M. Hare, The Language of Morals, Clarendon Press, Oxford, 1952., str. 18, kako bi objasnio razliku između indikativnih i imperativnih rečenica. Frastika se odnosi na sadržaj rečenice, dok se neustika odnosi na modalitet. Uzmimo sljedeće primjere rečenica, u nešto izmijenjenom obliku, iz H. Rottleuthner, „Marksistička i analitička teorija prava“" (prijevod T. Kurpis), Argumenti: časopis za društvenu teoriju i praksu 2, 1978., str. 196-197.

1. Činjenica je da A ide kući;

2. Pitanje je ide li A kući;

3. Dobro je da A ide kući;

4. Zapovijedam da A ide kući.

U svim navedenim primjerima frastika je ista (,A ide kući“), dok se rečenice razlikuju u neustici (ovisno radi li se o utvrđivanju, pitanju, vrednovanju ili zapovijedanju u navedenim primjerima).

21 M. Barberis, ,Za istinski realističku teoriju prava“ (prijevod L. Burazin), Revus 29, 2016., str. 27. Ako se držimo podjele smjerova u filozofiji prava na one jusnaturalističke i juspozitivističke, onda pravni realizam nesumnjivo predstavlja jednu varijantu juspozitivizma.

22 O pravnom realizmu vidi u D. Vrban, op. cit. u bilj. 4, str. 571-573, koji kao predstavnike skandinavskog pravnog realizma (početak 20. st.) navodi Šveđane Axela Hägerströma, Vilhelma Lundstedta i Karla Olivecronu i Danca Alfa Rossa, dok kao predstavnike američkog pravnog realizma (tridesete godine 20. st.) navodi Karla N. Llewellyna i Jeromea Franka. Posebno o skandinavskom pravnom realizmu u N. Visković, op. cit. u bilj. 9, str. 41-56. Za glavne predstavnike američkog i skandinavskog pravnog realizma, vidi i R. Guastini, „Girovagando nella filosofia giuridica del Novecento“, Materiali per una storia della cultura giuridica 48, 2018., str. 235-245.

${ }^{23}$ Ovakav pristup prikazu jedne pravne škole je preuzet od M. Barberis, op. cit. u bilj. 15. Budući da je svaki izbor (pa tako i ovaj izbor autora koji su ukratko predstavljeni u radu) subjektivan, spomenuo bih ovdje i neke druge pripadnike škole koji u radu nisu predstavljeni, a koje spominje i Barberis: Susanna Pozzolo (1975.) i Giovanni Damele (1975.). Što se tiče mlađih generacije škole, u studenom 2019. održana je konferencija Realismo genovese. Nuovi confini (Đenoveški realizam. Nove granice), sastanak đenoveških doktora prava. Širenje ideja đenoveške škole vidljivo je i kroz rad njenih alumnija na pravnim fakultetima u Argentini, Čileu, Italiji, Kolumbiji, Meksiku, Njemačkoj, Portugalu, Španjolskoj, Ujedinjenom Kraljevstvu i, naravno, Italiji. Vidi https://istitutotarello.org/2019/11/01/events-realismogenovese-nuovi-confini-genoa-nov-6-7-2019/ (4. XI. 2019.). 


\subsection{GIOVANNI TARELLO}

Giovanni Tarello (1934. - 1987.), osnivač đenoveške škole jedan je od najistaknutijih talijanskih filozofa i povjesničara prava. Objavljujući radove od sredine 50-ih godina, Tarello je dao jedan od najvećih doprinosa talijanskoj pravnoj znanosti u drugoj polovici 20. stoljeća. ${ }^{24}$ Bavio se, između ostalog, poviješću pravnih kodifikacija, teorijom i tumačenjem normativnog jezika i sociologijom prava. ${ }^{25}$ Intelektualni utjecaj na Tarella, pa tako i na đenovešku školu preko utjecaja na njenog utemeljitelja, imali su, kako navodi Chiassoni, američki pravni realisti, Norberto Bobbio, Alf Ross, Uberto Scarpelli, Chaïm Perelman, analitička filozofija jezika, analitička metaetika i povijest pravne kulture. ${ }^{26}$

Među brojnim temama kojima se bavio, posebno se ističe tumačenje koje je, prema Tarellu, najznačajnija tema u pravu. ${ }^{27}$ To je posebno vidljivo u radu iz 1966. Il "problema dell interpretazione": una formulazione ambigua, u kojem navodi da tumačenje mora postati „,središnja teorijska preokupacija“, koja je tada bila periferna. ${ }^{28}$ Taj rad je postavio temelje đenoveškoj školi i tezama kojima su se bavili Tarello i njegovi učenici u narednim godinama, kako ih navodi Chiassoni: ${ }^{29}$

1) fenomen tumačenja,,čini jezgru svakodnevne djelatnosti razvijenih pravnih sistema, među kojima i suvremenih kontinentalno-europskih";

2) nažalost, i paradoksalno - kako ističe Chiassoni - uz samo neke iznimke, taj fenomen učestalo nailazi na nerazumijevanje od strane pravnika i zanemaren je od strane teoretičara prava;

3) nerazumijevanje od strane pravnika može se smatrati posljedicom zanemarivanja od strane teoretičara prava, ali ne samo toga. Razlog tome je i, napominje Chiassoni, taj što su pravnici „,̌esto spremni i zainteresirani izvršitelji nezgrapnog skupa ideja škola egzegeze, historijskopravne škole, pojmovne jurisprudencije, pomiješane s idejama slobodnog prava, interesne jurisprudencije, idealističke filozofije i hermeneutičkih prijedloga - svega, mogli bismo reći, osim neprihvatljivog Kelsenovog 'formalizma'“;

$24 \mathrm{Na}$ internetskim stranicama Tarello instituta za filozofiju prava u Genovi (Istituto Tarello per la filosofia del diritto) naveden je djelomičan popis njegovih radova, kojih samo na toj listi ima gotovo 200: https://istitutotarello.org/publications/complete-bibliography-of-giovanni-tarello-1934-1987/ (19. X. 2019.).

25 Barberis, op. cit. u bilj. 15, str. 21. Kako kaže Barberis, bila su to „,vremena u kojima specijalizacija nije bila neizbježna sudbina" za svakog tko se bavio filozofijom prava, pa tako navodi da se Tarello uspješno bavio i poviješću institucija, i sociologijom prava i pravnom dogmatikom. Barberis, op. cit. u bilj. 15, str. 15. O značaju Tarella u talijanskoj pravnoj znanosti, vidi i S. Rodotà, „Ricordo di Giovanni Tarello“, Materiali per una storia della cultura giuridica 28, 1998., str. 3-12.

26 P. Chiassoni, ,The Age of Analysis: Logical Empiricism, Ordinary Language, and the Simple Truth of the Matter", A Treatise on Legal Philosophy and General Jurisprudence 12, Springer, Dordrecht, str. 659 .

27 Barberis, op. cit. u bilj. 15, str. 15.

28 P. Chiassoni, op. cit. u bilj. 25, str. 658-659. Usp. G. Tarello, „Il 'problema dell'interpretazione': una formulazione ambigua", Rivista internazionale di filosofia del diritto 43/2, 1966. str. 349-357.

29 P. Chiassoni, op . cit. u bilj. 25, str. 658-659. 
4) zanemarivanje od strane teoretičara prava može se smatrati posljedicom „zastarjele koncepcije njihovog zadatka, koja se temelji na normativističkoj predrasudi. Takva predrasuda, naprimjer, predlaže posvećivanje jednog poglavlja u udžbenicima tumačenju, uz ostala poglavlja u kojima se bavi, nepovezano, s drugim temama poput definicije (pojma) prava, pravnom normom, pravnim sistemom, važenjem i učinkovitošću ${ }^{30}$ pravnih normi“;

5) prema posljednjoj tezi vezanoj uz tumačenje, normativistička predrasuda mora biti odbačena; tumačenje mora postati središnja teorijska preokupacija.

Naglašavajući važnost tumačenja, Tarello je razvio dvije ideje. ${ }^{31}$ Prva je od tih ideja realistička, o tumačenju ovisna koncepcija pravnih normi, koja se temelji na strogom razlikovanju između pravne norme i pravne odredbe. Norma je rezultat tumačenja odredbe; odredbe su objekti tumačenja čije značenje (određeno tumačenjem) jesu norme. ${ }^{32}$ Tumačenje se, prema Tarellu, sastoji u ,pripisivanju značenja pravnim odredbama, tako da se utvrdi koje norme one izražavaju“. ${ }^{33}$ Druga ideja koju je Tarello razvio u svojim radovima jest ona o realističkoj teoriji tumačenja, u sklopu koje se bavi, između ostalog, prirodom i alatima tumačenja. ${ }^{34}$

Tarello naglašava višeznačnost pojma „tumačenja“, navodeći sljedeća značenja: ${ }^{35}$ prvo, tumačenje može označavati ,aktivnost koja se sastoji u samom utvrđivanju interpretativnih outputa koje je proizveo neki tumač u određenom kontekstu“; drugo, tumačenje možemo shvatiti kao „aktivnost koja se sastoji od prognoziranja kako će određena odredba biti protumačena od strane određenog tumača u određenom kontekstu“; treće, tumačenje možemo shvatiti kao „aktivnost koja se sastoji u odlučivanju o značenju odredbi“; i četvrto, tumačenje možemo shvatiti kao ,aktivnost koja se sastoji u pripisivanju značenja koje bi trebalo biti dano određenoj odredbi“. Od navedenih značenja samo ono treće (tumačenje-

30 Izraz 'efficacy’ preveden je kao ‘učinkovitost' pravne norme. Neki je još nazivaju, kako upućuje Burazin, 'efiktivnošću' ili ‘efikasnošću'. O učinkovitosti kao predikatu pravne norme (i pravnog sustava), vidi u L. Burazin, „Pojam prava i (društvena) učinkovitost - analitički pristup“, Pravni vjesnik 33 (3-4), 2017., str. 119 i dalje.

31 P. Chiassoni, op. cit. u bilj. 25, str. 659. Osim s dvije navedene Tarellove ideje, Chiassoni piše i realističkoj, o intepretaciji ovisnom teorijom o pravnim prazninama. Vidi infra pod III. 5. Pierluigi Chiassoni.

32 N. Visković, koji je prevodio i N. Bobbia, i G. Tarella, također polazi od strogog razlikovanja između pravne norme i pravne odredbe. Vidi N. Visković, 1981., op. cit. u bilj. 3, str. 185-191. i N. Visković, 2006., op. cit. u bilj. 3, str. 171-174. Generacijama pravnika obrazovanih na Viskovićevoj integralnoj teoriji prava ovo razlikovanje možda će se činiti trivijalno, međutim, u vrijeme kada je Tarello isticao ovu razliku (60-ih godina), to razlikovanje nije bilo u tolikoj mjeri općeprihvaćeno u teoriji prava. Usp. P. Chiassoni, op. cit. u bilj. 25, str. 659, o Tarellovom razlikovanju normi i odredbi (,disposizoni“, „enunciati normativi“): „Norms should be properly regarded as the outputs of the interpretation of provisions. Provisions are, in turn, those texts whose meanings, as determined by interpretation, are norms. Interpretation, as a narrowly and properly conceived activity, consists in the ascription of meaning to provisions, so as to determine which norms they do express."

33 P. Chiassoni, op. cit. u bilj. 25, str. 659. Vidi G. Tarello, op. cit. u bilj. 2, str. 9-10

34 P. Chiassoni, op. cit. u bilj. 25, str. 659. Vidi G. Tarello, op. cit. u bilj. 2, I. poglavlje Nozione di interpretazione, str. 1.-38. i VIII. poglavlje, L'argomentazione dell'interpretazione e gli schemi di motivazione dell'atribuzione di significato a documenti normativi, str. 341-396.

35 P. Chiassoni, op. cit. u bilj. 25, str. 659. Vidi G. Tarello, op. cit. u bilj. 2, VIII. poglavlje. O višeznačnosti pojma „tumačenja“, usp. i R. Guastini, op. cit. u bilj. 2, str. 351-358. 
odluka), prema Tarellu, ispravno označava tumačenje, jer samo u tom slučaju zaista dolazi do tumačenja pravne odredbe; sva ostala značenja jesu „,samo aktivnosti koje pretpostavljaju ili anticipiraju neko tumačenje-odluku i njegov output “ ${ }^{36}$

Osim prirode tumačenja, Tarello se također bavio i alatima tumačenja pa je tako predložio popis od 15 interpretativnih argumenata koji se koriste kao alati u tumačenju: ${ }^{37}$ 1) argument a contrario; 2) argument a simili ad simile (ili argument analogije - analogia legis); 3) argument a fortiori; 4) argument potpunosti pravnog reguliranja; 5) argument koherentnosti pravnog reguliranja; 6) psihološki argument; 7) historijski argument; 8) apagogički argument; 9) teleološki argument; 10) argument ekonomičnosti ili neredundantnosti; 11) argument ab exemplo (ili autoritativni argument); 12) sistematski argument; 13) naturalistički argument; 14) argument pravičnosti i 15) argument koji polazi od općih načela (ili analogia iuris). Ovih 15 interpretativnih argumenta predstavljaju skup alata kojima se tumači u pravu mogu koristiti kako bi, putem tumačenja pravnih odredbi kao objekata tumačenja, došli do rezultata tumačenja - pravne norme. ${ }^{38}$ Sam Tarello je, kako navodi Barberis, po pitanju tumačenja bio radikalni skeptik, tj. smatrao je da tumač „stvara" norme. ${ }^{39}$

\subsection{RICCARDO GUASTINI}

Riccardo Guastini (1946.) najpoznatiji je i najutjecajniji član đenoveške škole. ${ }^{40}$ Za razliku od Tarella, Guastini je po pitanju tumačenja umjereni skeptik, tj. smatra da tumač ne „stvara“ norme, nego da izabire između više mogućih značenja koja

36 P. Chiassoni, op. cit. u bilj. 25, str. 659-660.

37 Tarello je predložio četiri klasifikacije navedenih 15 argumenata. Prema prvoj podjeli, može se razlikovati argumente spefično pravne i one koji to nisu (među prvima bi bili sistematski argument, argument pravičnosti i argument koji polazi od općih načela), dok bi svi ostali bili u drugoj skupini. Prema drugoj podjeli, na tzv. logičke i nelogičke argumente (ovisno o raširenom shvaćanju o njihovoj prinudnosti - jer oni nisu i formalno prinudni), u prvoj bi skupini bili argument a contrario, argument $a$ simili ad simile, argument a fortiori, argument koherentnosti i argument potpunosti pravnog reguliranja, dok bi svi ostali bili u drugoj skupini. Prema trećoj podjeli, argumenti se dijele na potpune i nepotpune, gdje bi nepotpuni bili oni argumenti koji se moraju povezati s drugim argumentima da bi bili potpuni, a to su argument analogije, argument a fortiori, argument koherentnosti pravnog reguliranja i argument potpunosti pravnog reguliranja. Prema četvrtoj i posljednjoj podjeli, Tarello razlikuje konzervativne $\mathrm{i}$ nekonzervativne argumente (iako je ova podjela najrelativnija od navedenih, kako napominje): u prvu skupinu svrstava argument pravičnosti, argument koji polazi od općih načela, naturalistički argument, argument a contrario, psihološki argument i argument ekonomičnosti. Svi ostali argumenti bili bi tendencijski konzervativni. Detaljno o ovome u G. Tarello, L'Interpretazione della legge, Giuffrè, Milano, 1980., VIII. poglavlje. Usp. bilj. 2 za prijevod.

38 Usp. također s N. Visković, op. cit. u bilj. 3, str. 171-174.

39 Barberis, op. cit. u bilj. 15, str. 16.

$40 \mathrm{Na}$ internetskim stranicama Tarello instituta za filozofiju prava u Genovi (Istituto Tarello per la filosofia del diritto) naveden je djelomičan popis Guastinijevih radova: https://istitutotarello.org/ publications/works-of-riccardo-guastini/ (9. XI. 2019.). Ibid. Guastinijevu knjigu La sintassi del diritto preveo je L. Burazin pod naslovom Sintaksa prava (usp. bilj. 2) te tako u hrvatsku teoriju prava uveo analitički pristup pravu. Knjiga je postala obvezna literatura na kolegiju Teorija prava na Pravnom fakultetu Sveučilišta u Zagrebu i na kolegiju Teorija prava i države na Pravnom fakultetu Sveučilišta u Splitu. 
su dana samom tekstualnom formulacijom. ${ }^{41}$ Od brojnih Guastinijevih doprinosa teoriji prava, s kojima je započeo početkom 70-ih, u radu će biti spomenut njegov doprinos razlikovanju pravila i načela, implicitnim normama i ustavnoj teoriji kroz ideju konkretizacije ustavnih načela. ${ }^{42}$

Pravna načela, naravno, nisu nova tema u pravnoj znanosti. Međutim, od druge polovice 60-ih godina 20. stoljeća i utjecajnog članka Ronalda Dworkina The Model of Rules, pravna načela postaju stalna tema rasprava u teoriji prava. ${ }^{43}$ Značaj teme, posebno pitanje razlikovanja pravnih načela od pravnih pravila, uz brojne posljedice u teoriji prava (za teoriju normi, koncept pravnog sistema, odnos između prava i morala) ima i poseban značaj u primjeni prava, rješavanju sukoba između normi te načinu shvaćanja ustavnih odredbi koje izražavaju temeljna prava. ${ }^{44} \mathrm{U}$ teoriji prava obično se smatra, kako navodi Guastini, da se svaki pravni sustav sastoji od dva tipa normi: pravila i načela. ${ }^{45}$ Dok je pravno pravilo, s jedne strane, ,,pogodbeni iskaz

41 Barberis, op. cit. u bilj. 15, str. 16.

42 Guastini je u latinoameričkoj kulturi poznat kao ustavnopravni teoretičar. To se može objasniti fazom u kojoj se bavio ustavnopravnom tematikom, ali po svom cjelokupnom habitusu Guastini se bavi prvenstveno teorijom prava. M. Barberis, op. cit. u bilj. 15, str. 13, navodi da je Guastini ,,već imao tri filozofska života“: u prvom se ponajprije bavio marksizmom i marksističkim pravnim rječnikom, u drugom se bavio talijanskim ustavnim pravom, dok je u trećem razvio opću teoriju prava u stilu analitičke (Oxford-Cambridge) filozofije. Pregled đenoveške škole realizma ne može proći bez spominjanja analitičke filozofije jezika (vidi i P. Chiassoni, op. cit. u bilj. 25, str. 659 i P. Chiassoni, L'indirizzo analitico nella filosofia del diritto. I. da Bentham a Kelsen, Giappichelli, Torino, 2009. Moglo bi se reći, ako ćemo suditi po jasnoći i preciznosti jezičnog stila autora đenoveške škole, da je vidljiv utjecaj Wittgensteina odnosno analitičke filozofije i njegova Logičko-filozofskog traktata, toč. 4.116.: „Sve što se uopće može misliti može se misliti jasno. Sve što se uopće može izreći može se izreći jasno."Vidi L. Wittgenstein, Tractatus Logico-Philosophicus (prijevod C. K. Ogden), Project Guthenberg, 2010.

43 Riječ je o temi kojom se bavila većina značajnijih teoretičara prava posljednjih pola stoljeća (između ostalih, Ronald Dworkin, H. L. A. Hart i Joseph Raz) te o kojoj je u međuvremenu nastala opsežna literatura. Vjerojatno najutjecajnija teorija o razlikovanju pravnih pravila i načela (nastala pod djelomičnim utjecajem Ronalda Dworkina) jest ona Robert Alexyja, njemačkog teoretičara prava, osnivača utjecajne „Kielske škole“. O tome vidi u R. Alexy, A Theory of Constitutional Rights, Oxford University Press, Oxford, 2002., str. 44. i dalje. Sažeto govoreći, Alexy kaže da su pravna pravila i pravna načela dvije (i jedine dvije) vrste normi s različitom logičkom strukturom (dok se pravila ili primjenjuju ili ne primjenjuju, načela se mogu ostvariti u većoj ili manjoj mjeri); također, razlika je i u načinu rješavanja sukoba između dviju vrsta normi: dok kod pravila možemo primijeniti metapravila poput lex superior, lex posterior ili lex specialis, to u situaciji sukoba načela nije moguće; tu je potrebno primijeniti balansiranje. Balansiranje je tehnika ili metoda rješavanja sukoba između načela, te predstavlja jednu od središnjih ideja u Alexyjevoj teoriji prava. Značajne praktične implikacije ovog shvaćanja proizlaze iz činjenice da su temeljna prava zajamčena modernim ustavima u većini pravnih sistema shvaćena upravo kao načela. Budući da je balansiranje (koje je dio načela proporcionalnosti, ako koristimo terminologiju bližu sudskoj praksi i europskom pravu) jedna od predloženih metoda za rješavanje sukoba između temeljnih prava, literatura je vrlo opsežna, te se ovdje zadržavam samo na definiranju koncepta. Uputio bih samo na djelo M. Klatt, Institutionalized Reason: The Jurisprudence of Robert Alexy, Oxford University Press, Oxford, 2012., posebno str. 1-26.

Naravno, pravna načela nisu nova tema u pravnoj znanosti, ali od objave Dworkinova članka, koji je za cilj imao kritiku pravnog pozitivizma (konkretno, pozitivizma H. L. A. Harta i njegove navodne nemogućnosti objašnjavanja uloge pravnih načela u sudskom rasuđivanju), tema je kontinuirano u fokusu teorije prava. Vidi R. Dworkin, „,The Model of Rules“, University of Chicago Law Review 35/1, 1967. str. 22.

44 Vidi R. Alexy, „On the Structure of Legal Principles“, Ratio Juris 13/3, 2000., str. 294.

45 R. Guastini, op. cit. u bilj. 2, str. 77. 
koji povezuje neku pravnu posljedicu s nekim razredom činjenica - ako Č, onda $\mathrm{P}^{\text {“, }}$ pojam pravnog načela u teoriji „,nešto je složeniji, i prije svega, sporan“ ${ }^{46}$

Prema Guastiniju, pravna načela kao norme obilježavaju dvije karakteristike: temeljni karakter i neodređenost. ${ }^{47}$ Temeljni karakter norme, prema Guastiniju, odnosi se na „položaj“ norme u pravnom poretku i ima dva značenja: ${ }^{48}$ prvo je da su načela temeljne norme „u tom smislu što daju temelj i/ili vrijednosno (etičko-političko) opravdanje drugim normama“, dok je drugo to da „,nemaju ili ne zahtijevaju nikakav vrijednosni temelj, nikakvo etičko-političko opravdavanje, jer ih se u postojećoj pravnoj kulturi doživljava kao očevidno 'pravedne' ili 'ispravne' norme“. Načela su „bitna za identitet ili vrijednosnu fizionomiju“ nekog pravnog poretka. ${ }^{49}$ Druga je karakteristika načela njihova neodređenost, koja se odnosi na „sam sadržaj normi i/ili njihovu logičku strukturu“. ${ }^{50} \mathrm{Tzv}$. osobita neodređenost načela može poprimiti barem tri različita oblika, prema Guastiniju: ${ }^{51}$ prvi je otvoreno činjenično stanje; drugi je „otklonjivost“ ili ,derogabilnost“ (defeasibility), a treći je općenitost. Razlika između pravila i načela, u odnosu na prvi oblik osobite neodređenosti, jest ta što su pravila norme sa zatvorenim antecedentom (činjeničnim stanjem), dok su načela norme s otvorenim antecedentom (otvorenim činjeničnim stanjem). ${ }^{52}$ Antecedent norme je zatvoren, kako navodi Guastini, „kada su u normi iscrpno nabrojane činjenice u nazočnosti kojih nastupa pravna posljedica predviđena tom normom“, dok je antecedent otvoren kada ,u normi nisu iscrpno nabrojane činjenice u nazočnosti kojih nastupa odgovarajuća pravna

46 Ibid. Sporan, prije svega, jer su različiti autori predlagali različite načine razlikovanja pravila i načela (dok su neki također smatrali da ih se uopće ne može smisleno razlikovati). Na temu kriterija za razlikovanje pravila i načela, vidi P. Moniz Lopes, „The Syntax of Principles: Genericity as a Logical Distinction between Rules and Principles", Ratio Juris 30/4, 2017., str. 472 i dalje. O načinu shvaćanja načela u hrvatskoj pravnoj znanosti, vidi M. Keršić, „Legal Principles in the Discourse of Croatian Legal Science: What Qualifies a Norm as a Principle?", Romanian Journal of Comparative Law 9, 2018., str. 328-340.

Ovdje treba spomenuti i upotrebu formalne logike od strane đenoveške škole. Koristeći jednostavan primjer i jezik logike, pravnu normu općenito možemo rekonstruirati kao implikaciju u obliku ,,ako p, onda q“, gdje p označava neki razred činjenica, dok q označava odgovarajuću pravnu posljedicu. Usp. Guastini, op. cit. u bilj. 2, str. 77. Vidi i formalizaciju argumenata putem upotrebe formalne logike u P. Chiassoni, Tecnica dell'interpretazione giuridica, Il Mulino, Bologna, 2007., str. 295-310.

47 R. Guastini, op. cit. u bilj. 2, str. 77-84. Vidi također i R. Guastini, Interpretare e argomentare, Giuffrè, Milano, 2011., str. 173-180.

48 R. Guastini, op. cit. u bilj. 2, str. 78.

49 Ibid. Guastini navodi primjere iz talijanskog pravnog sistema: načelo diobe vlasti u ustavnom pravu, načelo privatne autonomije u građanskom pravu, načelo nullum crimen, nulla poena sine lege u kaznenom pravu i načelo lex posterior derogat priori u ukupnom pravnom poretku. Zbog pripadnosti istom krugu (kontinentalno-europskih) pravnih sistema, ova su načela prisutna i u hrvatskom pravnom poretku.

50 Ibid., str. 79

51 Ibid., str. 80.

52 Ibid. Neki autori smatraju, kako navodi Guastini, da su načela norme posve bez činjeničnog stanja, odnosno bez antecedenta. 
posljedica“" ${ }^{53}$ Kada govori o drugom obliku osobite neodređenosti pravnih načela, Guastini govori o „otklonjivosti“ ili „derogabilnosti“ (defeasibility): norma je neotklonjiva ,kada ne dopušta iznimke osim onih koje su izrijekom utvrđene njome ili drugim normama istog pravnog poretka“, dok je norma otklonjiva „kada dopušta implicitne iznimke, koje nisu utvrđene ni njome ni bilo kojom drugom normom pravnog poretka“" ${ }^{54}$ Značajna posljedica ovog razlikovanja jest ta da se otklonjivu normu ne može primijeniti putem jednostavnog deduktivnog rasuđivanja odnosno putem deduktivnog silogizma, jer ,pojavljivanje jedne od činjenica obuhvaćenih antecedentom (...) nije dovoljan uvjet da uslijedi odnosna pravna posljedica". 55 U trećem i zadnjem značenju osobite neodređenosti pravnih načela, općenitosti, Guastini podrazumijeva dvije stvari: dok su pravila „precizne“ norme koje su neposredno primjenjive na konkretne slučajeve, načela su općenite norme u sljedećem smislu: s jedne strane, „zahtijevaju formuliranje drugih normi - koje je 'konkretiziraju', ukazujući na 'provedbu' ili 'izvršenje' - bez kojih ne bi bila prikladna za rješavanje konkretnih slučajeva", dok, s druge strane, ta konkretizacija, provedba ili izvršenje može izvesti na različite i alternativne načine. ${ }^{56}$

Vezano za prethodno spomenutu potrebu konkretizacije načela, Guastini navodi kako sudačka primjena ustavnih načela,,uključuje (barem) četiri različiteintelektualne operacije: ${ }^{57}$ prvo, identificiranje načela kao takvih, odnosno ,pripisivanje statusa načela određenoj ustavnoj odredbi“; drugo, tumačenje, odnosno „pripisivanje značenja ustavnoj odredbi koja je (prethodno ili kontekstualno) identificirana kao odredba koja izražava načelo“; treće, „,balansiranje takvog načela s drugim

53 Ibid., str. 80. Kao primjer za otvoreni antecedent, može se navesti načelo jednakosti pred zakonom, čl. 14. st. 1. Ustava Republike Hrvatske: „Svatko u Republici Hrvatskoj ima prava i slobode, neovisno o njegovoj rasi, boji kože, spolu, jeziku, vjeri, političkom ili drugom uvjerenju, nacionalnom ili socijalnom podrijetlu, imovini, rođenju, naobrazbi, društvenom položaju ili drugim osobinama.“

54 Ibid., str. 81. Kao primjer za neotklonjivost, može se navesti čl. 2. Kaznenog zakona: „Nitko ne može biti kažnjen za djelo koje prije nego je počinjeno nije bilo utvrđeno zakonom ili međunarodnim pravom kao kazneno djelo, niti mu se može izreći kazna ili druga kaznenopravna sankcija koja nije bila određena zakonom.“, dok se kao primjer za otklonjivost može navesti čl. 40. Ustava Republike Hrvatske: „Jamči se sloboda savjesti i vjeroispovijedi i slobodno javno očitovanje vjere ili drugog uvjerenja“.

55 Ibid. Usp. N. Visković, op. cit. u bilj. 3, str. 263-265.

56 R. Guastini, op. cit. u bilj. 3, str. 81-82. Kao primjer može se navesti čl. 55. st. 1. Ustava Republike Hrvatske: „Svatko ima pravo na rad i slobodu rada“.

57 M. V. Ballestrero, R. Guastini, „Dialogando su principi e regole”, Materiali per una storia della cultura giuridica 47, 2017., str. 127 i dalje. Ove četiri faze se, prema Guastiniju, ne mogu (sa psihološkog stajališta) strogo razdijeliti, ali "s logičkog gledišta svaka od njih zaslužuje posebnu analizu”. Može se primijetiti da i Guastini, kao i Alexy, koristi balansiranje kao pojam kojim označava metodu rješavanja sukoba između načela. Ipak, ovdje ono ima drugačije, iako donekle slično značenje, od onoga koje koristi Alexy. Razlog tome je postojanje više različitih teorija balansiranja. Pogledaj R. Guastini, „Ponderazione. Un'analisi dei conflitti tra principi costituzionali“, Ragion pratica 26, 2006., str. 151. i dalje. U španjolskoj teoriji prava najutjecajnija verzija balansiranja (i drukčijeg razlikovanja pravila i načela) jest ona Manuela Atienze i Juana Ruiza Manera. Vidi M. Atienza, J. Ruiz Manero, Las piezas del derecho. Teoría de los enunciados juridicos, Editorial Ariel, S.A., Barcelona, 1996., str. 177., za tablicu koja sažeto prikazuje razlikovanje između dvije vrste pravila i dvije vrste načela (pravila, reglas - de acción i de fin te načela, principios - in sentido estricto i directrices) i M. Atienza, J. Ruiz Manero, „Rules, Principles, and Defeasibility“, The Logic of Legal Requirements, Oxford, Oxford University Press, 2012., str. 238-253, o pravilima, načelima i balansiranju. Za prikaz aktualnih rasprava oko balansiranja u španjolskoj teoriji prava, pogledaj M. F. Nuñez, „La ponderación: análisis de la situacíon del debate en España, Doxa 40, 2017., str. 355-384. 
suprotstavljenim načelima kako bi se odredilo načelo koje će biti primijenjeno" i, četvrto, ,preciziranje ili konkretizacija načela kako bi se konstruiralo pravilo koje će se primijeniti na konkretni slučaj“. Primjeri ustavnih načela koje Guastini navodi jesu načelo slobode izražavanja, pravo na privatnost te pravo na zdrav život. ${ }^{58}$ Guastini dodaje, u realističkom stilu, da je ,preciziranje ili konkretizacija načela autentično stvaranje prava (odnosno, pravnih pravila) ". ${ }^{59} \mathrm{U}$ tom smislu, dodaje, citirajući nekadašnjeg predsjednika američkog Vrhovnog suda, Charlesa Evansa Hughesa, da je ,ustav ono što suci kažu da jest" ${ }^{60}$

Guastini je Tarellovom shvaćanju realističke, o tumačenju ovisne koncepcije pravnih normi dodao ideju implicitnih ili prešutnih normi: to su norme koje (a) ne mogu biti smatrane značenjem niti jedne pravne odredbe i (b) identificirane su putem logičkog zaključivanja ili retoričke argumentacije iz prethodno identificiranih normi ${ }^{61}$ Držeći se prethodno spomenutih tema načela, a posebno ustavnih načela, možemo spomenuti neizražena ustavna načela kao oblik implicitnih normi: to su načela „'bez odredbe', to jest ona koja nisu izrijekom formulirana u nijednoj (ustavnoj (...)) normativnoj odredbi, nego su ih razvili ili „konstruirali“ tumači. ${ }^{62}$

\subsection{PAOLO COMANDUCCI}

Paolo Comanducci (1950.), najpoznatiji predstavnik đenoveške škole u Latinskoj Americi, izvorno pravni povjesničar, a kasnije se bavi i etikom, metaetikom i

58 M. V. Ballestrero, R. Guastini, op. cit. u bilj. 55. Primjetno je da su navedena načela primjeri iz talijanskog pravnog poretka (čl. 21., čl. 3. i čl. 32) važeća i u hrvatskom pravnom poretku (čl. 38 ., čl. 35. i čl. 70. Ustava Republike Hrvatske, "Narodne novine”, broj 56/90, 135/97, 08/98, 113/00, 124/00, 28/01, 41/01, 55/01, 76/10, 85/10, 05/14). U tom smislu, razmatranja iz rada predlažu opće teorijsku shemu, odnosno analizu koraka u postupku primjene ustavnih načela, ali i konkretne primjere iz talijanskog pravnog sustava uz opservacije koje su primjenjive direktno u hrvatskom pravnom sustavu.

59 M. V. Ballestrero, R. Guastini, op. cit. u bilj. 56, str. 137.

60 Ibid.

61 P. Chiassoni, op. cit. u bilj. 25, str. 659.

62 R. Guastini, op. cit. u bilj. 2, str. 83-84. O razlikovanju tumačenja i pravnog konstruiranja, vidi ibid., str. 357-358. Kao primjere neizraženih ili implicitnih načela u hrvatskom pravnom poretku L. Burazin, M. Krešić, I. Tucak, Priručnik za teoriju prava - praktični dio, Naklada Breza, Zagreb, 2018. str. 45-46, navode načelo pravne sigurnosti, načelo legitimnih očekivanja, načelo jasnoće i određenosti zakonskih odredaba, načelo pravičnog suđenja i načelo zabrane arbitrarnosti. Navedena načela su, kako autori navode, ,neizražena načela ustavnog ranga koja su razvili ili 'konstruirali' hrvatski ustavni sudci u okviru prakse Ustavnog suda Republike Hrvatske, izvodeći ih iz pojma vladavine prava (čl. 3. Ustava Republike Hrvatske)“. S druge strane, načelo dispozicije (dispozitivnosti), načelo oficioznosti i načelo pravnog interesa u građanskom procesnom pravu jesu ,neizražena načela zakonskog ranga koja su (procesualistička) doktrina i sudci konstruirali iz čitavog niza pravih pravila Zakona o parničnom postupku“. Neizraženo načelo postaje izraženo, kako dalje navode autori, ,,u trenutku kada ga zakonodavac izrijekom formulira u pravnoj odredbi“, što se u našem pravnom poretku dogodilo s načelom proporcionalnosti koje je promjenama ustava iz 2000. godine („Narodne novine“, broj 113/00) postalo izraženo načelo u čl. 16. st. 2. Ustava Republike Hrvatske. 
filozofijom prava.$^{63}$ Među Comanduccijevim djelima, u kojima se bavi navedenim temama, ističu se Assagi di metaetica ${ }^{64}$ (o metaetičkim pitanjima, poput odnosa etike i metaetike, radikalnog emotivizma nasuprot radikalnog objektivizma, i o etičkim konceptima, poput 'jednakosti' i 'pravednosti') i Assagi di metaetica $d u e^{65}$ (o odnosu prava, morala i politike, konceptu tolerancije, ljudskim pravima, sudačkom rasuđivanju, među kojim i o razlikovanju pravila i načela).

\subsection{MAURO BARBERIS}

Mauro Barberis (1956.) bavi se poviješću liberalizma i konstitucionalizma, a posebno je zanimljiv jedan oblik pravnog evolucionizma koji zastupa, blizak i austrijskoj školi ekonomije. ${ }^{66}$ Pravni je evolucionizam ,proširenje pozitivističke i realističke tradicije koje kritizira kreacionizam: sklonost pripisivanja pojava volji i idejnom nacrtu jednog ili više stvaratelja. (...) Međutim, pravo nije moguće svesti na puki zbroj tih akata [akata ljudske proizvodnje, op. a.] ili na njihove pojedinačne učinke. Ni zakonodavci ni suci ne mogu polagati pravo na stvaranje prava, nego samo na sudjelovanje u njegovoj proizvodnji (...) Samo pravo nije puki skup normi, nego njihov sustav ili poredak. Poput svih sustava, i pravo ima proizlazeća obilježja, tj. obilježja koja su dodatak obilježjima njegovih dijelova, i koja su određena evolucijom međusobnih odnosa tih dijelova“" ${ }^{67}$ Barberis je uputio i interne kritike đenoveškom interpretativnom skepticizmu, ${ }^{68}$ te je i značajno doprinio samom prikazivanju glavnih ideja škole. ${ }^{69}$

63 Barberis, op. cit. u bilj. 15, str. 17. Među Comanduccijevim djelima, u kojima se bavi navedenim temama, ističu se Assagi di metaetica iz 1992. (o metaetičkim pitanjima, poput odnosa etike i metaetike, radikalnog emotivizma nasuprot radikalnog objektivizma, str. 23-92, i o etičkim konceptima, poput 'jednakosti' i 'pravednosti' str. 93-194) i Assagi di metaetica due iz 1998. (o odnosu prava, morala i politike, str. 3-15, konceptu tolerancije, str. 17-30, ljudskim pravima, str. 31-53, sudačkom rasuđivanju, među kojim i o razlikovanju pravila i načela, str. 81-95). Paolu Comanducciju trebalo bi dati više prostora u ovom pregledu, međutim, zbog želje za zadržavanjem sažetosti rada, njemu je posvećeno nešto manje prostora. Također, vodio sam se idejom da rad da pregled predstavnika đenoveške škole iz različitih generacija, tako da je veća pažnja (a posljedično manja drugim autorima, u nekim slučajevima neopravdano njihovom značaju) dana Giovanniju Tarellu, Riccardu Guastiniju, Pierluigiju Chiassoniju i Giovanniju Battisti Rattiju.

64 P. Comanducci, Assagi di metaetica, Analisi e diritto, Giappichelli, Torino, 1992.

65 P. Comanducci, Assagi di metaetica due, Analisi e diritto, Giappichelli, Torino, 1998.

66 M. Barberis, op. cit. u bilj. 15, str. 18. Kao i u prethodnom slučaju s Paolom Comanducijem, Mauru Barberisu posvećeno je daleko manje prostora nego što je njegov doprinos đenoveškoj školi. $\mathrm{O}$ razlogu takvog pristupa, vidi supra bilj. 61.

67 M. Barberis, op. cit. u bilj 20, str. 27.

68 M. Barberis, „Lo scetticismo imaginario. Nove obiezioni agli scettici à la genoise“, Analisi $e$ diritto, Giappichelli, Torino, 2001., str. 1-36.

69 Vidi M. Barberis, op. cit. u bilj. 15; također, M. Barberis, op. cit. u bilj. 10. 


\subsection{PIERLUIGI CHIASSONI}

Pierluigi Chiassoni (1961.) bavi se, između ostalog, daljnjim razvijanjem teorije tumačenja, gdje se može istaknuti knjiga Tecnica dell'interpretazione giuridica, u kojoj, uz bavljenje antinomijama i prazninama, daje logičke formalizacije različitih argumenta. ${ }^{70}$ Chiassoni se bavio i sjevernoameričkom ekonomskom analizom prava i poviješću pravnog pozitivizma. ${ }^{71}$ Ovdje ću spomenuti Chiassonijevu analizu antinomija i pravnih praznina. ${ }^{72}$ Chiassoni razlikuje tri moguća značenja pojma antinomija: ${ }^{73}$ prema prvom shvaćanju $\left(\mathrm{A}_{1}\right)$, antinomija je ,svaka inkompatibilnost između dvije norme (za koje se pretpostavlja da su) istovremeno važeće, barem prima facie za jedan pravni poredak“ ${ }^{74}$ Prema $\left(\mathrm{A}_{2}\right)$, antinomija je ,svaka inkompatibilnost između dvije norme koja se ne može ukloniti pomoću tumačenja“, dok je prema trećem $\left(\mathrm{A}_{3}\right)$ antinomija ,svaka inkompatibilnost između dvije norme, koja se ne može ukloniti, niti prevladati primjenom unaprijed određenog kriterija rješavanja“" ${ }^{75}$ Chiassoni integrira Rossovu taksonomsku trodiobu na potpune antinomije, jednostrano djelomične i dvostrano djelomične ${ }^{76} \mathrm{~s}$ klasičnom podjelom na antinomije in abstracto i in concreto ${ }^{77} \mathrm{Uz}$,tradicionalne“ kriterije ili pravila o

70 P. Chiassoni, op. cit. u bilj. 45, str. 295-310. Tako je, primjerice, argument a contrario (u svojoj varijanti ,produktivne funkcije“ - o četiri varijante argumenta a contrario - vidi ibid., str. 296-298) jezikom simboličke logike iskazan na sljedeći način:

$[(\mathrm{x})(\mathrm{CxàSx})] a ̀ O[(\mathrm{x})(\sim \mathrm{Cxà} \mathrm{Sx})]$.

Navedeno možemo čitati kao: „Ako za sve x vrijedi da, ako je x C, da je onda x S, onda se mora zaključiti da, za sve $\mathrm{x}$, ako je x ne-C $(\sim \mathrm{C})$, da je $\mathrm{x}$ i ne-S $(\sim \mathrm{S}) “$. Vidi i P. Chiassoni, Interpretation without Truth: A Realistic Enquiry, Springer, Dordrecht, 2019., gdje u prvom poglavlju (str. 1-15) autor iznosi temeljne postavke analitičkog realizma. Kad govorimo o Chiassoniju i tumačenju, treba spomenuti i njegov prilogu u obliku ,,interpretativnih igara“, koje definira kao ,individualnu ili društvenu aktivnost koja se sastoji u pripisivanju značenja dijelu diskursa (rečenici ili nizu rečenica). Interpretativne igre su, po definiciji, lingvističke igre: igre koje se igraju po pravilima jezika (i netko bi mogao reći, igre koje se igraju s riječima pomoću riječi)“. Prije definicije ,,interpretativnih igara“, Chiassoni definira ,igru“ u širem smislu kao „,bilo koju individualnu ili društvenu aktivnost koja se odvija u skladu sa vlastitim pravilima“, dok linguističku igru definira, slijedeći Wittgensteina, kao ,bilo koju društvenu aktivnost koja se odvija putem jezika - ili, preciznije, putem prirodnog jezika, u skladu sa vlastitim gramatičkim i semantičkim pravilima“. Vidi P. Chiassoni,,,Interpretive games: Statutory Construction Through Gricean Eyes“, Analisi e diritto, Giappichelli, Torino, 1999., str. 86. i dalje. Vidi o tome više i u P. Chiassoni, 2019., op. cit. u bilj. 68, str. 49-74.

71 P. Chiassoni, 2009., op. cit. u bilj. 40. Vidi M. Barberis, op. cit. u bilj. 14, str. 18-19.

72 Razlog tome (iako bi predstavljanje tumačenja vjerojatno reprezentativnije predstavljalo Chiassonijev opus) jest taj što je o tumačenju u kontekstu đenoveške škole nešto već rečeno pod III. 1. Giovanni Tarello (naravno, ne implicirajući da Chiassoni u potpunosti dijeli spomenuta stajališta). Upravo zbog važnosti antinomija i pravnih praznina u pravnoj praksi upućuje se na Chiassonijev rad o njima. Chiassonijeve ideje o antinomijama su iznimno sažeto iznesene, dok za pravne praznine upućujem na P. Chiassoni, op. cit. u bilj. 25, str. 660-664.

73 P. Chiassoni, "Materiali per una teoria delle antinomie", Materiali per una storia della cultura giuridica 36, 2006., str. 209-210. O razlozima i svrsi razlikovanja tri moguća značenja pojma antinomije, vidi Ibid.

74 Ibid. Chiassoni dodaje napomenu prima facie, jer do antinomije može doći i kada je jedna od normi iz drugog pravnog poretka; ali i u tom slučaju se, prima facie, ,moraju promatrati i/ili primijeniti kao norme jednog pravnog poretka, po nekoj normi unutrašnjeg ili međunarodnog poretka“.

75 Ibid., str. 210.

76 A. Ross, op. cit. u bilj. 11, str. 128-132. Usp. R. Guastini, op. cit. u bilj. 2, str. 269-283.

77 P. Chiassoni, op. cit. u bilj. 71, 212 i dalje. 
rješavanju antinomija (lex posterior, lex superior i lex specialis) ${ }^{78}$, zanimljivo je pitanje kako postupati u situacijama kada dođe i do sukoba između samih pravila. Tu ima i jednostavno rješivih situacija, poput onih u kojoj su antinomične ranija ustavna norma i kasnija zakonska norma, ali i onih koje se i ne čine tako lako rješive: što kada su antinomične ranija specijalna norma i kasnija opća ili viša opća i niža specijalna ${ }^{79} \mathrm{U}$ talijanskoj teoriji prava došlo se do sljedećih zaključaka: ${ }^{80}$ hijerarhijski je kriterij uvijek jači od vremenskog, ali uspostavljanje jednog stalnog odnosa u slučajevima kada je jedan od kriterija u sukobu onaj specijalnosti nije moguć. Kriterij specijalnosti, ovisno o tome kako se tumači, može biti i najslabiji (onda kada je slabiji i od vremenskog), ali može biti i najjači (onda kada nadjačava i hijerarhijski); u situacijama u kojima je jedan od kriterija u sukobu kriterij specijalnosti, kako ističe Norberto Bobbio, ,nema automatskih rješenja, već se do rješenja treba doći putem interpretacije“. ${ }^{81}$

\subsection{GIOVANNI BATTISTA RATTI}

Giovanni Battista Ratti (1975.) posebno se bavi primjenom logike na analizu pravnih fenomena. Kako navodi Barberis, on je primjer autora koji spaja ideje đenoveškog pravnog realizma i argentinske teorije prava ${ }^{82}$ I Ratti je pisao o đenoveškoj školi. ${ }^{83}$ Od brojnih doprinosa Rattija, mogu se istaknuti knjige koje se bave pitanjima pravne norme i pravnog sistema: El gobierno de las normas i The Logic of Legal Requirements: Essays on Defeasibility (druga u koatorstvu s

78 N. Visković, op. cit. u bilj. 3, str. 240.-241. Vidi i N. Bobbio,,Des critères pour résoudre les antinomies“, Dialectica 18/4, 1964., str. 237-258.

79 O tome više u N. Bobbio, op. cit. u bilj. 2, str. 123-135.

80 Ibid., str. 135.

81 Ibid. U takvim slučajevima, u kojima nema kriterija za rješavanje antinomija, „kriterij nad kriterijima“ - kako dalje navodi Bobbio - jest kriterij pravednosti ili ,pravila da treba jednako postupati s jednakima, a nejednako s nejednakima“.

${ }^{82}$ M. Barberis, op. cit. u bilj. 15, str. 20. Argentinska teorija prava je posredno, preko Carlosa Cossija i njegove egološke teorije prava imala iznimno značajan utjecaj i na domaću teoriju prava, budući da je Nikola Visković, kao predstavnik integralne teorije prava, značajan dio ideja preuze upravo od egološke teorije prava Carlosa Cossija, o čemu je i napisao knjigu. Vidi N. Visković, Pravo kao kultura: egološka teorija prava Carlosa Cossija, Izdavački centra Rijeka, Rijeka, 1990. Ipak, Carlos Cossio je bitno manje utjecajan u Argentini, te se pod argentinskom teorijom prava ovdje misli na Carlosa Eduarda Alchourróna i Eugenia Bulygina. Njihovo djelo Normative systems, Springer Verlag, Wien, 1971., predstavlja jedno od najboljih logičkih analiza prava i najutjecajnijih djela iz teorije prava u drugoj polovici 20. stoljeća uopće. Dvadeset godina nakon prvog izdanja knjige, Georg Henrik von Wright, utemeljitelj deontičke logike i Wittgensteinov nasljednik na Cambridgeu knjigu je smatrao ,najkompletnijom monografskom studijom o temeljnim pitanjima u teoriji prava izvršenoj koristeći instrumente moderne logike i konceptualne analize“ (vidi M. Atienza, ,20th-Century Philosophy of Law in Argentina“, A Treatise on Legal Philosophy and General Jurisprudence 12, 2016., str. 824.). U tom smislu, argentinsku teoriju prava, pod utjecajem Alchourróna, karakterizira bitna uloga logike u pravu. Vidi, primjerice, Alchourrón, „On Law and Logic“, Ratio Juris 9/4, str. 331-348.

83 G. B. Ratti, „Norme, logica e realismo giuridico“, Materiali per una storia della cultura giuridica 38, 2008.; J. Ferrer Beltrán, G. B. Ratti, El realismo jurídico genovés, Marcial Pons, Madrid, 2011. 
Jordijem Ferrerom Beltránom iz Girone) ${ }^{84}$ U prvoj spomenutoj knjizi posebno se ističe poglavlje XI., koje govori o primjeni teorije skupova, odnosno matematičke logike na pravo. ${ }^{85} \mathrm{Ne}$ ulazeći dublje u teoriju skupova i matematičku logiku ${ }^{86} \mathrm{može}$ se navesti da se Ratti bavi, između ostalog, identificiranjem elemenata od kojih se sastoji pravo, shvaćeno kao skup ili zbroj skupova. ${ }^{87}$ Ostavljajući po strani ovu temu koja nije do sada obrađivana u hrvatskoj teoriji prava, možemo spomenuti drugo djelo koje se bavi pojmom otklonjivosti ili derogabilnosti (defeasibility). ${ }^{88}$ Otklonjivošću se, osim prava, bave i logika, epistemologija i filozofija morala, između ostalih. ${ }^{89}$ Pojam otklonjivosti, kao obilježja norme koja dopušta implicitne iznimke, koje nisu utvrđene njom samom ili drugim normama, od značaja je, između ostalog, za pojam prava, utvrđivanje važećih pravnih normi, tumačenje, rješavanje sukoba između normi i sudačko rasuđivanje. S obzirom na obim literature o otklonjivosti u pravu, a i također s obzirom na to da je nakon prijevoda Sintakse prava pojam uveden u hrvatsku teoriju prava, zaključit ću samo s jednim primjerom koji pokazuje problem

84 G. B. Ratti, El gobierno de las normas, Marcial Pons, Madrid, 2013. i J. Ferrer Beltrán, The Logic of Legal Requirements: Essays on Defeasibility, Oxford University Press, Oxford, 2012. Postoji kontinuirana i intenzivna suradnja i razmjena ideja između talijanskih, španjolskih, argentinskih autora, francuskih i portugalskih autora koji se bave teorijom prava. U studenom 2019. u Genovi, na Tarello institutu za filozofiju prava održan je 25. po redu Seminario Italo-Franco-Luso-Spagnolo di Teoria del Diritto. U tom smislu ovaj rad ima skromnu pretenziju da hrvatskoj pravnoj znanosti, posebice teoriji prava, približi trendove, uvjetno rečeno, romanskog kulturnog kruga u teoriji prava. U prosincu 2014. u Genovi, također na Tarello institutu za filozofiju prava održan je Genoa-Slavic Seminar in Legal Theory, na kojem su sa „slavenske“ strane sudjelovali autori iz Hrvatske (Luka Burazin i Tina Oršolić Dalessio), Poljske, Slovenije, Bosne i Hercegovine i Srbije. Informacije o navedenim seminarima dostupne su na internetskim stranicama Tarello instituta za filozofiju prava: https://istitutotarello.org/ (20. X. 2019.). Što se tiče pravnog sistema i sistematizacije prava, vidi i G. B. Ratti, Sistema giuridico e sistemazione del diritto, Analisi e diritto, Giappichelli, Torino, 2008. posebno Poglavlje I. Il concetto di sistema nel diritto, str. 3-35 i Poglavlje III., Sistematizzazione e sistemazione del diritto, str. 69-92.

85 G. B. Ratti, op. cit. u bilj. 82, str. 241-263.

86 O teoriji skupova i matematičkoj logici uvodna je literatura dostupna i na online stranicama Prirodoslovno-matematičkih fakulteta pod odgovarajućim web-stranicama kolegija Teorija skupova na studiju Matematike (Zagreb, Split, Osijek). O primjeni teorije skupova na pravo više (detaljno) u G. B. Ratti, op. cit. u bilj. 82, XI. poglavlje.

87 G. B. Ratti, op. cit. u bilj. 82, str. 247. Ratti ovdje razmatra tri moguće opcije odgovora na pitanje koji elemenati sačinjavaju pravo kao skup ili zbroj skupova: prvu, da su elementi u pitanju pravne odredbe; drugu, da su elementi u pitanju značenja pripisana (ili potencijalno pripisana) pravnim odredbama i treću, da se radi o značenjima „,koja je moguće deducirati iz logičkih posljedica, držeći se određenih, prethodno postavljenih, pravila zaključivanja, tako da se ti setovi sastoje i od izraženih i od neizraženih normi“".

88 O tom je pojmu prethodno bilo riječi supra pod III. 2. Riccardo Guastini, gdje je ukratko definirano značenje pojma. O otklonjivosti, osim u J. Ferrer Beltrán, G. B. Ratti, op. cit. u bilj. 82, str. 11-38, vidi i B. Brożek, Defeasibility of Legal Reasoning, Zakamycze, Krakow, 2004. i P. Chiassoni, „La defettibilità nel diritto“, Materiali per una storia della cultura giuridica 38, 2008., str. 471-506.

89 J. Ferrer Beltrán, G. B. Ratti, op. cit. u bilj. 82, str. 1. 
otklonjivosti u slučaju upotrebe standardne deontičke logike ${ }^{90}$ općenito, koji navode Ferrer Beltrán i Ratti. ${ }^{91}$

\section{ZAVRŠNA RAZMATRANJA}

Na kraju izlaganja nekih ideja đenoveške škole i njenih autora, istaknuo bih ideje koje mogu imati i praktične implikacije u primjeni prava. Prvo, prijedlog popisa interpretativnih argumenata koje je izložio Tarello (ne smatrajući pritom da uvjerljivost popisa proizlazi iz argumenta autoriteta) predstavlja sistematizirani popis na temelju kojeg se mogu raditi empirijska istraživanja o pravnoj argumentaciji i kojim se, naravno, mogu služiti tumači. ${ }^{92}$ Drugo, razlikovanje pravila i načela kao dviju vrsta normi ima posljedicu za rasuđivanje, posebno ono sudačko: dok se pravila primjenjuju putem supsumcije, načela se ne mogu (odnosno, zbog karakteristike tzv. osobite neodređenosti $i^{93}$ ne bi se smjela) primjenjivati na isti način: ona zahtijevaju konkretizaciju kako bi se primijenila, posebno u slučajevima sukoba između normi. Treće, ideja otklonjivosti (derogabilnosti), koja označava svojstvo neke norme da dopušta implicitne iznimke koje nisu utvrđene njome ni drugim normama pravnog poretka također utječe na rasuđivanje i rješavanje sukoba između normi. Razlog je taj što se otklonjivu normu ne može primijeniti putem deduktivnog rasuđivanja upravo zbog toga što su moguće implicitne iznimke koje za posljedicu imaju to da pojavljivanje jedne od činjenica obuhvaćenih činjeničnim stanjem (antecedentom) nije dovoljan uvjet za nastupanje pravne posljedice propisane pravnom normom. ${ }^{94}$ I kao četvrto, „tradicionalni“ kriteriji ili pravila o rješavanju antinomija (lex superior, lex posterior i lex specialis) i sami mogu doći u sukob te su u tom smislu u talijanskoj teoriji prava predloženi kriteriji za rješavanje sukoba između samih kriterija hijerarhije, vremena i specijalnosti, te u tom smislu možemo govoriti o metakriterijima.$^{95}$ Vraćajući se hrvatskoj teoriji prava, gledano iz perspektive spoznaja iz talijanske teorije prava, može se istaknuti potencijal upotrebe simboličke logike na pravo, posebice na argumentaciju. ${ }^{96}$

90 Pojam deontičke logike, prethodno spomenut supra u bilj. 80, označava granu simboličke logike koja se bavi propozicijama o dopuštenom, obveznom i zabranjenom (deontičkim modalitetima). Naziv dolazi od grčk. $\tau \dot{o} \delta \varepsilon ́ o v$, što znači “dužnost”. Vidi G. H. von Wright, „Deontic Logic“, Mind 60, 1951., str. 1-15.

91 J. Ferrer Beltrán, G. B. Ratti, op. cit. bilj. 82, str. 18-19, navode primjer nazvan Tweety. Primjer se, naravno, mutatis mutandi, može primijeniti i u pravu; naveden je samo kao jednostavan uvodni problem. Radi se o situaciji u kojoj prihvaćamo univerzalni sud „Sve ptice lete“ (u simbolima: ‘(x) PxàLx)’, i sud da Tweety, budući da je pingvin, ne leti (kako slovo P već označava ptice, za pingvine koristim slovo $G$ (u simbolima: '(x) Gxà Lx \& Gaà La'). Ovim se dolazi u situaciju u kojoj imamo opravdane razloge vjerovati da Tweety i leti i ne leti ('La \& La'), jer je, u isto vrijeme, i ptica i pingvin ('Pa \& Ga'). Ovaj problem obično se rješava takozvanim načelom prioriteta specifičnosti, prema kojem specifičnija informacija otklanja (engl. defeats, od defeasibility) općenitiju.

92 Kao primjer, vidi Ž. Harašić, Sudska argumentacija, Pravni fakultet u Splitu, Split, 2010., posebno str. 121-122.
93 Vidi supra, III. 2.
94 R. Guastini, op. cit. u bilj. 2, str. 80.
95 Vidi supra, III. 5.
96 Vidi supra, III. 5. i III. 6. 


\section{LITERATURA}

1. Alchourrón, C. E., "On Law and Logic", Ratio Juris 9/4, 1996.

2. Alchourrón, C. E., Bulygin, E., Normative Systems, Springer Verlag, Beč, 1971.

3. Alexy, R., "On the Structure of Legal Principles", Ratio Juris 13/3, 2000.

4. Alexy, R., A Theory of Constitutional Rights, Oxford University Press, Oxford, 2002.

5. Atienza, M., "20th-Century Philosophy of Law in Argentina", A Treatise on Legal Philosophy and General Jurisprudence 12, Dordrecht, Springer, 2016.

6. Atienza, M.; Ruiz Manero, J., Las piezas del derecho. Teoría de los enunciados juridicos, Editorial Ariel, S. A., Barcelona, 1996.

7. Atienza, M.; Ruiz Manero, J., "Rules, Principles, and Defeasibility", The Logic of Legal Requirements, Oxford University Press, Oxford, 2012.

8. Ballestrero, M. V.; Guastini, R., "Dialogando su principi e regole", Materiali per una storia della cultura giuridica 47, 2017.

9. Barberis, M., "Lo scetticismo immaginario. Nove obiezioni agli scettici à la genoise", Analisi e diritto, 2001.

10. Barberis, M., Manuale di filosofia del diritto, Giappichelli, Torino, 2011.

11. Barberis, M., „Genoa's Realism: A Guide for the Perplexed“, Revista Brasileira de Filosofia 240, 2013.

12. Barberis, M., „El realismo jurídico europeo-continental“, Enciclopedia de filosofía y teoría del derecho 1, Instituto de Investigaciones Jurídicas, UNAM, Ciudad de México, 2015.

13. Barberis, M., „Za istinski realističku teoriju prava“ (prijevod L. Burazin), Revus 29, 2016.

14. Bobbio, N., „Des critères pour résoudre les antinomies“, Dialectica 18/4, 1964.

15. Bobbio, N., Eseji iz teorije prava (prijevod N. Visković i Ž. Anzulović), Logos, Split, 1988.

16. Brożek, B., Defeasibility of Legal Reasoning, Zakamycze, Krakow, 2004.

17. Burazin, L., „Pojam prava i (društvena) učinkovitost - analitički pristup“, Pravni vjesnik 33 (3-4), 2017.

18. Burazin, L.; Krešić, M.; Tucak, I., Priručnik za teoriju prava - praktični dio, Naklada Breza, Zagreb, 2018.

19. Castignone, S., Diritto, linguaggio, realtà. Saggi sul realismo giuridico, Giappichelli, Torino, 1995.

20. Chiassoni, P., "L'ineluttabile scetticismo della 'scuola genovese", Analisi e diritto, Giappichelli, Torino, 1998.

21. Chiassoni, P., "Interpretive game: Statutory Construction Through Gricean Eyes", Analisi e diritto, Giappichelli, Torino, 1999.

22. Chiassoni, P., "Materiali per una teoria delle antinomie", Materiali per una storia della cultura giuridica 36, 2006.

23. Chiassoni, P., Tecnica dell'interpretazione giuridica, Il Mulino, Bologna, 2007. 
24. Chiassoni, P., "La defettibilità nel diritto", Materiali per una storia della cultura giuridica 38, 2008.

25. Chiassoni, P., L'indirizzo analitico nella filosofia del diritto. I. da Bentham a Kelsen, Giappichelli, Torino, 2009.

26. Chiassoni, P., „The Age of Analysis: Logical Empiricism, Ordinary Language, and the Simple Truth of the Matter", A Treatise on Legal Philosophy and General Jurisprudence 12, Springer, Dordrecht, 2016.

27. Chiassoni, P., Interpretation without Truth: A Realistic Enquiry, Springer, Dordrecht, 2019.

28. Comanducci, P., Assagi di metaetica, Analisi e diritto, Giappichelli, Torino, 1992.

29. Comanducci, P., Assagi di metaetica due, Analisi e diritto, Giappichelli, Torino, 1998.

30. Dworkin, R., “The Model of Rules”, University of Chicago Law Review 35/1, 1967.

31. Faralli, C., "Legal Philosophy in Italy in the 20th Century", A Treatise on Legal Philosophy and General Jurisprudence 12, Springer, Dordrecht, 2016.

32. Fernandez Núñez, M., "La ponderación: análisis de la situación del debate en España”, Doxa 40, 2017.

33. Ferrer Beltrán, J.; Ratti, G. B., El realismo jurídico genovés, Marcial Pons, Madrid, 2011.

34. Ferrer Beltrán, J.; Ratti, G. B., The Logic of Legal Requirements: Essays on Defeasibility, Oxford University Press, Oxford, 2012.

35. Gianformaggio, L., „Realismi giuridici italiani“, Analisi e diritto, Giappichelli, Torino, 1991.

36. Guastini, R., „Dalle fonti alle norme“, Analisi e diritto, Giappichelli, Torino, 1992.

37. Guastini, R., „Ponderazione. Un’ analisi dei conflitti tra principi costituzionali“, Ragion pratica 26, 2006.

38. Guastini, R., Interpretare e argomentare, Giuffrè, Milano, 2011.

39. Guastini, R., „Realismo e antirealismo nella teoria dell'interpretazione“, Ragion pratica 17, 2011.

40. Guastini, R., „Redefinicija pravnog realizma“ (prijevod M. Franić), Revus 19, 2013.

41. Guastini, R., „A Realistic View on Law and Legal Cognition“, Revus 27, 2015.

42. Guastini, R., Sintaksa prava (prijevod L. Burazin), Naklada Breza, Zagreb, 2016.

43. Guastini, R., „Girovagando nella filosofia giurdicia del Novecento“, Materiali per una storia della cultura giuridica 48, 2018.

44. Harašić, Ž., Sudska argumentacija, Pravni fakultet u Splitu, Split, 2010.

45. Hare, R. M., The Language of Morals, Clarendon Press, Oxford, 1952.

46. Keršić, M., „Legal Principles in the Discourse of Croatian Legal Science: What Qualifies a Norm as a Principle?“", Romanian Journal of Comparative Law 9, 2018.

47. Klatt, M., Institutionalized Reason: The Jurisprudence of Robert Alexy, Oxford University Press, Oxford, 2012.

48. Leiter, B., „Legal Realisms, Old and New“, Valparaiso University Law Review 47, 2013. 
49. Moniz Lopes, P., „The Syntax of Principles: Genericity as a Logical Distinction between Rules and Principles“, Ratio Juris 30/4, 2017.

50. Pino, G., „Interpretazione cognitiva, interpretazione decisoria, interpretazione creative“", Rivista di Filosofia del diritto 1, 2013.

51. Ratti, G. B., „Norme, logica e realismo giuridico“, Materiali per una storia della cultura giuridica 38, 2008.

52. Ratti, G. B., Sistema giuridico e sistemazione del diritto, Analisi e diritto, Giappichelli, Torino, 2008.

53. Ratti, G. B., El gobierno de las normas, Marcial Pons, Madrid, 2013.

54. Rodotà, S., „Ricordo di Giovanni Tarello“, Materiali per una storia della cultura giuridica 28, 1998.

55. Ross, A., On Law and Justice, University of California Press, Berkeley, 1958.

56. Rottleuthner, H., „Marksistička i analitička teorija prava“ (prijevod T. Kurpis), Argumenti: časopis za društvenu teoriju i praksu 2, 1978.

57. Tarello, G., „Il ‘problema dell'interpretazione’: una formulazione ambigua“, Rivista internazionale di filosofia del diritto 43/2, 1966.

58. Tarello, G., L'interpretazione della legge, Giuffrè, Milano, 1980.

59. Tarello, G. „Argumentacija tumačenja i sheme obrazlaganja u pridavanju značenja normativnim tekstovima“ (prijevod VIII. poglavlja knjige L'interpretazione della legge, N. Visković i S. Šućin), Zbornik za teoriju prava 4, 1990.

60. Visković, N., Pojam prava: prilog integralnoj teoriji prava, Logos, Split, 1981.

61. Visković, N., Pravo kao kultura: egološka teorija prava Carlosa Cossija, Izdavački centra Rijeka, Rijeka, 1990.

62. Visković, N., „Alf Ross“, Zbornik radova Pravnog fakulteta u Splitu 18, 1981.

63. Visković, N., Teorija države i prava, Birotehnika, Zagreb, 2006.

64. von Wright, G. H., „Deontic Logic“, Mind 60, 1951.

65. Vrban, D., Država i pravo, Golden Marketing, Zagreb, 2003.

66. Wittgenstein, L., Tractatus Logico-Philosophicus (prijevod C. K. Ogden), Project Guthenberg, 2010.

\section{Popis propisa:}

1. Kazneni zakon, Narodne novine, broj 125/11, 144/12, 56/15, 61/15, 101/17, 118/18, $126 / 19$.

2. Ustav Republike Hrvatske, Narodne novine, broj 56/90, 135/97, 08/98, 113/00, 124/00, 28/01, 41/01, 55/01, 76/10, 85/10, 05/14.

3. Ustav Replike Italije (La Costituzione della Repubblica Italiana), Gazzetta Ufficiale n. 298 del 27. XII. 1947.

\section{Mrežni izvori:}

1. Hrvatska enciklopedija. Leksikografski zavod Miroslav Krleža - Teorije o pravu: http://www.enciklopedija.hr/Natuknica.aspx?ID=49999 (pristupljeno 4. XI. 2019.). 
2. Stanford Encyclopedia of Philosophy - Legal Positivism: https://plato.stanford.edu/ entries/legal-positivism/ (pristupljeno 21. X. 2019.).

3. Tarello Institute for Legal Philosophy: https://istitutotarello.org/ (pristupljeno 20. X. 2019.).

4. Tarello Institute for Legal Philosophy - Bibilografija Riccarda Guastinija: https:// istitutotarello.org/publications/works-of-riccardo-guastini/ (pristupljeno 9. XI. 2019.).

5. Tarello Institute for Legal Philosophy - Bibliografija Giovannija Tarella; https://istitutotarello.org/publications/complete-bibliography-of-giovannitarello-1934-1987/ (pristupljeno 19. X. 2019.).

6. Tarello Institute for Legal Philosophy: Realismo Genovese. Nuovi confini: https:// istitutotarello.org/2019/11/01/events-realismo-genovese-nuovi-confini-genoanov-6-7-2019/ (pristupljeno 4. XI. 2019.).

\section{GENOESE SCHOOL OF LEGAL REALISM}

This paper presents some fundamental ideas of Genoese legal realism, a school of thought that emerged in the second half of the $20^{\text {th }}$ century, and its most prominent members. The paper aims to point out the relevance of certain contemporary ideas in the Italian theory of law for Croatian legal science and their practical implications. Structurally, the paper first outlines the characteristics of legal realism in general (Scandinavian and American legal realism), and then the characteristics of Genoese legal realism as one of its variants. Representatives of the school discussed in the paper are Giovanni Tarello, Riccardo Guastini, Paolo Comanducci, Mauro Barberis, Pierluigi Chiassoni and Giovanni Battista Ratti, while the following is discussed in the paper: the idea of the central role of interpretation and the ambiguity of the term; a list of 15 arguments that can (or should) serve as a tool for interpreters; characteristics and differentiation of rules and principles (as two types of norms); interpretation and method of application of constitutional principles; implicit (tacit) norms; antinomies and criteria for resolving conflicts that arise between the criteria for resolving conflicts between antinomies; the application of logic in law through the application of set theory and the notion of defeasibility.

Key words: Italian legal theory, legal realism, legal norm, interpretation, antinomies 